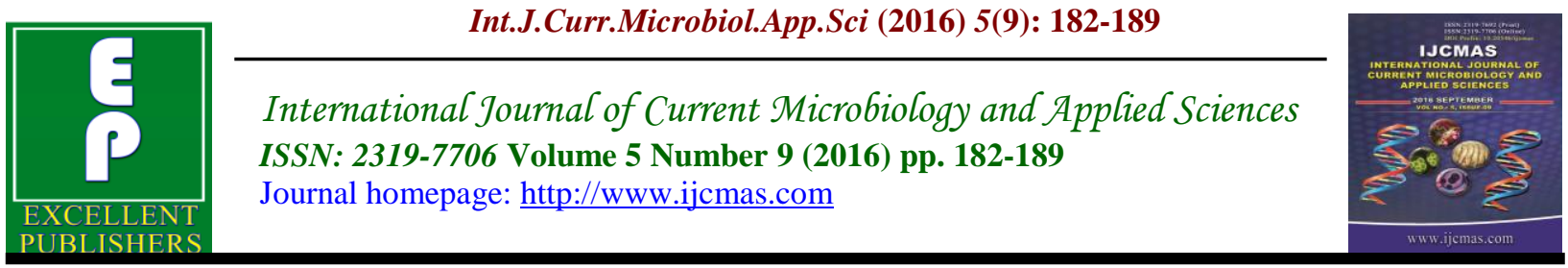

Original Research Article

http://dx.doi.org/10.20546/ijcmas.2016.509.020

\title{
Studies on Molds from Vegetable Waste, Cattle Dung Slurry and Biogas Digester Effluent
}

\author{
V.S. Patil ${ }^{1 *}$ and H.V. Deshmukh ${ }^{2}$ \\ ${ }^{1}$ Department of Microbiology, Lal Bahadur Shastri College of Arts, Science and Commerce, \\ Satara-415002, Maharashtra, India \\ ${ }^{2}$ Department of Microbiology, Yashavantrao Chavan Institute of Science, \\ Satara-415001, Maharashtra, India \\ *Corresponding author
}

\section{A B S T R A C T}

Keywords

Biomethanation, molds, amylolytic, proteolytic, lipolytic, cellulolytic, ligninolytic.

\section{Article Info}

Accepted:

13 August 2016 Available Online:

10 September 2016
Biomethanation is the anaerobic digestion of biodegradable organic matter in an enclosed space under controlled conditions of temperature, moisture, $\mathrm{pH}$, etc. The different types of microorganisms mainly bacteria, yeast, molds and actinomycetes are involved in biogas production process. Hydrolytic microorganisms play an important role in the hydrolysis step of biomethanation. The present paper deals with the study of molds from vegetable waste slurry, cattle dung slurry and biogas digester effluent. The biomethanation experiment was carried out in 5 litre capacity digester under ambient temperature conditions. Standard plate count of molds from vegetable waste slurry, cattle dung slurry and digester effluents were found to be $4.1 \times 10^{2}, 2.78 \times 10^{3}$ and $7.73 \times 10^{3}$ colonies $/ \mathrm{mL}$ respectively. In present study six molds were isolated and identified from each vegetable waste slurry and digester effluent whereas four molds were isolated and identified from cattle dung slurry using standard methods. Further all the mold isolates were tested for their potential to produce hydrolytic enzymes. This study has provided useful information about the molds associated with substrates and digester effluent that have important role in biogas generation.

\section{Introduction}

Vegetable waste is produced in large quantities during harvesting, poor and inadequate transportation, storage facilities, marketing practices and processing of vegetables. The collection, transportation and disposal of vegetable waste is a very serious problem today. The present unscientific treatment methods results in environmental pollution (Kumar et al., 2009).
Biomethanation is an attractive treatment option for vegetable wastes and play a triple role. First, it is a method of converting the energy contained in biomass into a biogas (Naik et al., 2010). Second, it is a method of recycling of organic wastes into stable soil additives, that is, valuable liquid fertilizer (Chami and Vivanco, 2007). Third, it is a method of wastes treatment aimed at a reduction of their hazardous effects on the environment (Kumar et al., 2009). 
Biomethanation is accomplished by a consortium of microorganisms working synergistically. Aerobic, facultative anaerobic and obligate anaerobic (methanogenic and non methanogenic) microflora are responsible for transformation of organic matter into biogas. Generally four main reactions occur during the entire process of the biomethanation: hydrolysis, acidogenesis, acetogenesis and methanogenesis (Nijaguna, 2012; Charles et al., 2009; Khanal, 2008; Davidsson, 2007). The hydrolysis step degrades both insoluble complex organic matter and high molecular weight compounds into soluble monomers in order to allow their transport through microbial cell membrane (Nijaguna, 2012). This reaction is catalyzed by extracellular enzymes (amylase, proteases, lipases, cellulases and ligninases) produced by hydrolytic and fermentative microorganisms. The aim of the present work was to identify mold isolates obtained from vegetable waste slurry, cattle dung slurry and effluent of biogas digester and to determine their potential to produce hydrolytic enzymes.

\section{Materials and Methods}

\section{Collection and preparation of samples}

Vegetable wastes for the present study were collected from the local vegetable market. The collected wastes were further segregated, shredded separately and ground in a kitchen blender to make paste. The physico-chemical analysis of vegetable waste was determined according to standard methods (APHA, 1998).

\section{Biomethanation of vegetable waste at 5} litre (L) level

Biomethanation study was carried out in a floating dome design type of $5 \mathrm{~L}$ capacity locally fabricated digesters. Inoculum was obtained from an active mesophilic digester of cattle dung based biomethanation plant located at Degaon village, M.I.D.C., Satara (M.S.), India. The $5 \mathrm{~L}$ digesters were operated at organic loading rate (OLR) $0.320 \mathrm{~g} \mathrm{VS} / 1 . \mathrm{d}$ and $\mathrm{pH} 7.0$ of substrate under ambient temperature conditions with two cycles of 20 days hydraulic retention time (HRT). The volumes of biogas were recorded daily. Combustibility testing and \% methane were also determined.

\section{Standard Plate Count (SPC) and Isolation of molds from vegetable waste, cattle dung slurry and digester effluent}

A one $\mathrm{mL}$ well mixed portions of the vegetable waste slurry, cattle dung slurry and digester effluent were subjected to serial dilutions and SPC for molds were carried out in triplicates using Martin Rose Bengal Agar (MRBA) medium. Plates were incubated at room temperature for 72 hours to get practicable colonies and then counts were recorded. The representative mold isolates were preserved in triplicates on MRBA slants at refrigeration temperature for further studies.

\section{Identification of mold isolates}

The preliminary identification of the mold isolates upto genus level was done on the basis of colonial, morphological and microscopic observation of the wet mounts with reference to Barnett and Hunter (1972), Domsch et al (1980), Aneja (2001), Gilman (2001) and Nagamani et al ( 2006). The confirmation of these mold isolates at species level was done at National Fungal Culture Collection of India, Mycology and Plant Pathology Group, Agharkar Research Institute, Pune, M.S., India. 


\section{Demonstration of enzymatic capabilities of mold isolates}

Starch agar, Skim milk agar, Gelatin agar, Tributyrin agar, Czapek Dox Agar medium containing carboxy-methyl cellulose and Mineral salt medium (MSM) agar containing lignin with methylene blue as indicator dye were used for determining amylolytic, caseinolytic, gelatinolytic, lipolytic, cellulolytic and ligninolytic potential of mold isolates respectively. The individual cultures were spot inoculated onto respective media plates and incubated at room temperature for 48-72 hours. Amylolytic activity was detected by exposing the starch agar plates to iodine crystals for 5 minutes to observe the starch degradation zone. Skim milk agar plates and tributyrin agar plates were observed for clear zones around growth which indicated caseinolytic and lipolytic activity respectively. Gelatin agar plates were flooded with Fraziers reagent to detect gelatinolytic activity of mold isolates. Cellulolytic activity was detected by flooding the plates with $1 \%$ congo red for 20 minutes at room temperature followed by washing with $1 \mathrm{M}$ sodium chloride solution. A clear zone around the growth against the dark red background was taken as indication of cellulose activity (Lu et al., 2004). The MSM-lignin agar plates were monitored for fungal growth and decolorization of methylene blue dye (Bandounas et al., 2011).

\section{Results and Discussion}

Potato (Solanum tuberosum L.), Onion (Allium cepa L.), Cabbage (Brassica oleracea L. var. capitata), Cauliflower (Brassica oleraceae L. var. botrytis), Tomato (Lycopersicon esculentum Mill.) and Brinjal (Solanum melongena L.) wastes dominated the composition of vegetable waste. The paste prepared from these wastes was used for biomethanation study. The moisture content of the waste was found to be $89.50 \%$. The chemical oxygen demand and biochemical oxygen demand were $174000 \mathrm{mg} / \mathrm{kg}$ and $97150 \mathrm{mg} / \mathrm{kg}$ respectively. Starch, cellulose, hemicelluloses, lignin, fat and proteins were present in $9900 \mathrm{mg} / \mathrm{kg}, \quad 8700 \mathrm{mg} / \mathrm{kg}$, $2400 \mathrm{mg} / \mathrm{kg}, 2200 \mathrm{mg} / \mathrm{kg}, 4000 \mathrm{mg} / \mathrm{kg}$ and $9081 \mathrm{mg} / \mathrm{kg}$ respectively. The high moisture and carbohydrate content indicated its suitability for biomethanation.

Biomethanation of vegetable waste at $5 \mathrm{~L}$ level was carried out at HRT 20 days, OLR $0.320 \mathrm{~g} \mathrm{VS} / \mathrm{l} . \mathrm{d}, \mathrm{pH} 7.0$ of influent and ambient temperature conditions $\left(30-40{ }^{\circ} \mathrm{C}\right)$. Range of biogas produced was 510$1340 \mathrm{~mL} / \mathrm{d}$, total amount of biogas produced in 40 days experiment was found to be $40515 \mathrm{~mL}$ and average amount of biogas was $0.633 \mathrm{~L} / \mathrm{g}$ VS added $/ \mathrm{d}$. The biogas burning test produced blue flame indicating rich methane content in the biogas. Gas chromatographic analysis of biogas revealed $59 \%$ methane.

SPC of molds from vegetable waste slurry, cattle dung slurry and digester effluents were determined using MRBA plates and incubating at room temperature for 72 hours (Table 1).

Six molds were isolated and identified from vegetable waste slurry, which included Aspergillus niger, Aspergillus sp., Cunninghamella echinulata, Alternaria raphani, Penicillium aff. granulatum and Penicillium sp., while four mold were isolated and identified from cattle dung slurry which included Aspergillus niger, Aspergillus sp., Trichoderma pseudokoningii and Penicillium sp. Six molds were isolated and identified from digester effluent included Aspergillus niger, 
Aspergillus $\quad$ sp., $\quad$ Trichoderma longibrachiatum, Trichoderma pseudokoningii, Penicillium aff. granulatum and Penicillium sp. (Table 2-4). Figure 1 represents colonial morphology of mold isolates obtained from vegetable waste slurry, cattle dung slurry and digester effluent.

It was observed that some of the mold isolates were common to vegetable waste slurry and digester effluent, cattle dung slurry and digester effluent (Table 5). The results showed that large number of molds was introduced by these two inoculums in the anaerobic digester, and many of the molds from this inoculums got established in the anaerobic digester and caused hydrolytic and methanogenic activities leading to generation of biogas from organic matter.

Table 6 represents the enzymatic capabilities of selected mold isolates obtained from vegetable waste slurry, cattle dung slurry and digester effluent. All the mold isolates obtained from vegetable waste slurry, cattle dung slurry and digester effluent showed strong amylolytic, gelatinolytic, caseinolytic, lipolytic, cellulolytic and ligninolytic activity. Thus, it is evident that these hydrolytic molds along with other hydrolytic microorganisms from the digester play an important role in transformation of organic matter into intermediates that are further utilized by other microorganisms to produce biogas.

Table.1 SPC of molds from different sources

\begin{tabular}{|l|l|}
\hline Source & SPC of molds (colonies/mL) \\
\hline Vegetable waste slurry & $4.10 \times 10^{2}$ \\
\hline Cattle dung slurry & $2.78 \times 10^{3}$ \\
\hline Digester effluent & $7.73 \times 10^{3}$ \\
\hline
\end{tabular}

Table.2 Identification of molds from vegetable waste slurry

\begin{tabular}{|l|l|l|}
\hline Isolate code No. & Morphological identification & Family \\
\hline VWM-1 & Aspergillus niger gr. & Trichocomaceae \\
\hline VWM-2 & Aspergillus sp. & Trichocomaceae \\
\hline VWM-3 & Cunninghamella echinulata (Thaxt.)Thaxt. & Cunninghamellaceae \\
\hline VWM-4 & Alternaria raphani J.W.Groves and Stolko & Pleosporaceae \\
\hline VWM-5 & Penicillium aff. granulatum Bainier & Trichocomaceae \\
\hline VWM-6 & Penicillium sp. & Trichocomaceae \\
\hline
\end{tabular}

Table.3 Identification of molds from cattle dung slurry

\begin{tabular}{|l|l|l|}
\hline Isolate code No. & Morphological identification & Family \\
\hline DSM-1 & Aspergillus niger gr. & Trichocomaceae \\
\hline DSM-2 & Aspergillus sp. & Trichocomaceae \\
\hline DSM-3 & Trichoderma pseudokoningii Rifai & Hypocreaceae \\
\hline DSM-4 & Penicillium sp. & Trichocomaceae \\
\hline
\end{tabular}


Table.4 Identification of molds from digester effluent

\begin{tabular}{|l|l|l|}
\hline Isolate code No. & Morphological identification & Family \\
\hline EM-1 & Aspergillus niger gr. & Trichocomaceae \\
\hline EM-2 & Aspergillus sp. & Trichocomaceae \\
\hline EM-3 & Trichoderma longibrachiatum Rifai & Hypocreaceae \\
\hline EM-4 & Trichoderma pseudokoningii Rifai & Hypocreaceae \\
\hline EM-5 & Penicillium aff. granulatum Bainier & Trichocomaceae \\
\hline EM-6 & Penicillium sp. & Trichocomaceae \\
\hline
\end{tabular}

Table.5 Molds found common to anaerobic digester effluent and to that of vegetable waste slurry and cattle dung slurry

\begin{tabular}{|l|l|l|}
\hline Sr.No. & Materials & Common mold isolates \\
\hline 1 & \multirow{2}{*}{$\begin{array}{l}\text { Vegetable waste slurry and digester } \\
\text { effluent }\end{array}$} & 1) Aspergillus niger gr. \\
\cline { 3 - 3 } & & 2) Aspergillus sp. \\
\cline { 3 - 3 } & & 3) Penicillium aff. granulatum Bainier \\
\hline & & 4) Penicillium sp. \\
\hline 2 & $\begin{array}{l}\text { Cattle dung slurry and digester } \\
\text { effluent }\end{array}$ & 1) Aspergillus niger gr. \\
\cline { 3 - 3 } & & 2) Aspergillus sp. \\
\hline & & 3) Trichoderma pseudokoningii Rifai \\
\cline { 3 - 3 } & & 4) Penicillium sp. \\
\hline
\end{tabular}

Table.6 Enzymatic capabilities of selected mold isolates

\begin{tabular}{|c|c|c|c|c|c|c|c|c|}
\hline \multirow[b]{2}{*}{ Sr. No. } & \multirow[b]{2}{*}{ Mold isolate } & \multirow[b]{2}{*}{ Source } & \multicolumn{6}{|c|}{ Enzyme production } \\
\hline & & & $\begin{array}{l}\text { Amylas } \\
\mathrm{e}\end{array}$ & $\begin{array}{l}\text { Caseina } \\
\text { se }\end{array}$ & $\begin{array}{l}\text { Gelatina } \\
\text { se }\end{array}$ & Lipase & $\begin{array}{l}\text { Cellulas } \\
\mathrm{e}\end{array}$ & $\begin{array}{l}\text { Ligninas } \\
\mathrm{e}\end{array}$ \\
\hline 1. & $\begin{array}{l}\text { Aspergillus niger } \\
\text { gr. }\end{array}$ & $\begin{array}{l}\text { Vegetable } \\
\text { waste,Cattle dung } \\
\text { slurry and Effluent }\end{array}$ & + & + & + & + & + & + \\
\hline 2. & Aspergillus sp. & $\begin{array}{l}\text { Vegetable } \\
\text { waste,Cattle dung } \\
\text { slurry and Effluent }\end{array}$ & + & + & + & + & + & + \\
\hline 3. & $\begin{array}{l}\text { Cunninghamella } \\
\text { echinulata }\end{array}$ & Vegetable waste & + & + & + & + & + & + \\
\hline 4. & $\begin{array}{l}\text { Trichoderma } \\
\text { longibrachiatum }\end{array}$ & Effluent & + & + & + & + & + & + \\
\hline 5. & $\begin{array}{l}\text { Trichoderma } \\
\text { pseudokoningii }\end{array}$ & $\begin{array}{l}\text { Cattle dung slurry and } \\
\text { Effluent }\end{array}$ & + & + & + & + & + & + \\
\hline 6. & $\begin{array}{l}\text { Alternaria } \\
\text { raphani }\end{array}$ & Vegetable waste & + & + & + & + & + & + \\
\hline 7. & $\begin{array}{l}\text { Penicillium aff. } \\
\text { granulatum }\end{array}$ & $\begin{array}{l}\text { Vegetable waste and } \\
\text { Effluent }\end{array}$ & + & - & + & + & + & + \\
\hline 8. & Penicillium sp. & $\begin{array}{l}\text { Vegetable waste, } \\
\text { Cattle dung slurry and } \\
\text { Effluent }\end{array}$ & + & + & + & + & + & + \\
\hline
\end{tabular}

(+) positive, (-) negative 
Fig.1 Colonial morphology of mold isolates obtained from vegetable waste, cattle dung slurry and digester effluent
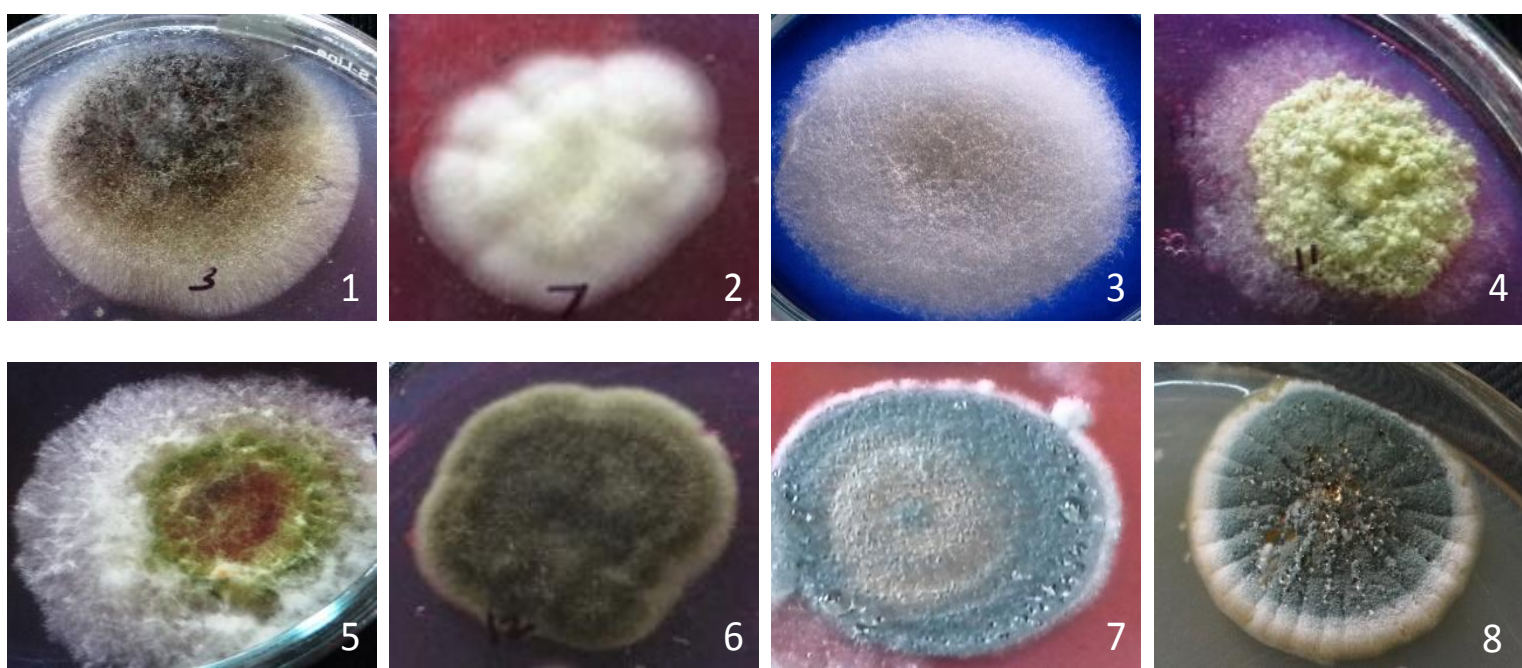

1=Aspergillus niger, $2=$ Aspergillus sp., $3=$ Cunninghamella echinulata,

4=Trichoderma longibrachiatum, 5=Trichoderma pseudokoningii, 6=Alternaria raphani, 7=Penicillium affinity granulatum, 8=Penicillium $\mathrm{sp}$.

There are reports on isolation and identification of molds from different substrates and digester effluent. Deshmukh (2004) identified Aspergillus sp., Fusarium sp., Neurospora sp., Penicillum sp., Tricoderma sp. from digester effluent run on mixture of distillery waste and Ipomoea weed. Kale (1986) isolated Aspergillus, Cladosporium, Fusarium, Mucor, Penicillium, Rhozopus and Candida from anaerobic lagoons of distillery waste treatment. The hydrolytic capabilities of these molds isolated from different soil samples has been reported by several researchers (Gupta, 2015; Manoorkar and Gachande, 2015; Kaur and Joshi, 2015; Reddy et al., 2014; Saleem et al., 2013; Chukwudi and Bamidele, 2013; Devi and Kumar, 2012; Khokhar et al., 2012).

In conclusion, SPC of molds from vegetable waste slurry, cattle dung slurry and digester effluents were found to be $4.1 \times 10^{2}, 2.78 \mathrm{X}$
$10^{3}$ and $7.73 \quad$ X $10^{3}$ colonies $/ \mathrm{mL}$ respectively. The mold isolates found were the species of Aspergillus, Cunninghamella, Trichoderma, Alternaria and Penicillium. The aerobic and facultative anaerobic, hydrolytic molds isolated from digester effluent included Aspergillus niger, Aspergillus sp., Trichoderma longibrachiatum, Trichoderma pseudokoningii, Penicillium aff. granulatum and Penicillium sp. The hydrolytic molds common to this digester effluent and to that vegetable waste slurry and cattle dung slurry included Aspergillus niger, Aspergillus sp., Trichoderma pseudokoningii, Penicillium aff. granulatum and Penicillium sp. This indicated that these hydrolytic molds probably have come from primary inoculum materials and acclimatized in the digester and contributed to the biogas production along with the help of other microorganisms. 


\section{Acknowledgements}

Researchers are thankful to the Principal, Yashavantrao Chavan Institute of Science, Satara, M.S., India for providing laboratory facilities for the research work.

\section{References}

Aneja, K.R. 2001. Experiments in Microbiology, Plant pathology and Biotechnology. New Age International Publishers (P) Ltd., New Delhi. 4: 157-162.

APHA, A.W.W.A. and W.E.F. 1998. Standard methods for the examination of water and wastewater. 20th edition, American Public Health Association, American Water Works Association and Water Environmental Federation, Washington, D. C., USA .

Bandounas, L., Wierckx, N.J., de Winde, J.H. and Ruijssenaars, H.J. 2011. Isolation and characterization of novel bacterial strain exhibiting ligninolytic potential. BMC Biotechnol., 11(94): 111.

Barnett, H.L. and Hunter, B.B. 1972. Illustrated Genera of Imperfect fungi. 3rd edn., Burgess Publishing Co., Minneapolis.

Chami, R. and Vivanco, E. 2007. Biogas potential: Identification and classification of different types of biomass available in Chile for the generation of biogas. Project for Renewable Energy and Deutsche Gesellschaft fur Technische Zusammenarbeit (GTZ) GmbH (German Technical Co-operation). Pp. 82.

Charles, W., Walker, L., Cord-Ruwisch, R. 2009. Effect of pre-aeration and inoculums on the start-up of batch thermophilic anaerobic digestion of municipal solid waste. Biores.
Technol., 100: 2329-2335.

Chukwudi, U.S. and Bamidele, I. 2013. Production and characterisation of amylase by fungi isolated from soil samples at Gwagwalada, FCT. Abuja - Nigeria Report and Opinion. 5(7):44-53.

Davidsson, A. 2007. Increase of biogas production at wastewater treatment plants. Ph. D. Thesis, Lund University, Lund, Sweden.

Deshmukh, H.V. 2004. Studies on biomethanation potential of common troublesome weeds in combination with some agro-based organic substrates and industrial wastes with emphasis on microbiological and pollution abatement aspects. Ph. D. Thesis, Shivaji University, Kolhapur, India.

Devi, M.C. and Kumar, M.S. 2012. Isolation and screening of lingo-cellulose hydrolytic saprophytic fungi from dairy manure soil. Annals of Biol. Res., 3(2): 1145-1152.

Domsch, K.H., Gams, W. and Anderson, T.H. 1980. Compendium of Soil Fungi. Vols. 1 and 2. Academic Press, London.

Gilman, J.C. 2001. A Manual of Soil Fungi. 2nd Indian edition, Biotech Books. Delhi.

Gupta, C., Jain, P., Kumar, D., Dixit, A.K. and Jain, R.K. 2015. Production of cellulase enzyme from isolated fungus and its application as efficient refining aid for production of security paper. Int. J. Appl. Microbiol. Biotechnol. Res., 3: 11-19.

Kale, S.C. 1986. Microbiology of Anaerobic Lagoons. Ph. D. Thesis, Shivaji University, Kolhapur, India.

Kaur, H.P. and Joshi, D. 2015. Optimization of cellulase produced by fungus isolated from water. World J. Pharm. Pharma. Sci., 4(2): 521-534. 
Khanal, S.K. 2008. Anaerobic biotechnology for bioenergy production principles and applications. Wiley-Blackwell, Singapore.

Khokhar, I., Haider, M.S., Mushtaq, S. and Mukhtar, I. 2012. Isolation and screening of highly cellulolytic filamentous fungi. J. Appl. Sci. Environ. Manage., 16(3): 223-226.

Kumar, S., Bhattacharyya, J.K., Chakrabarti, A.V., Devotta, T. and Akolkar, A. 2009. Assessment of the status of municipal solid waste management in metro cities, state capitals, class I cities, and class II towns in India: An insight. Waste Manage., 29: 883-895.

Lu, W.J., Wang, H.T., Nie, Y.F., Wang, Z.C., Huang, D.Y., Qiu, X.Y. and Chen, J.C. 2004. Effect of inoculating flower stalks and vegetable waste with ligno-cellulolytic microorganisms on the composting process. J. Environ. Sci. Health, Part B. 39(5-6): 871-887.

Manoorkar, V.B. and Gachande, B.D. 2015. Influence of physical factors on extracellular lipase production in Storage seed- borne fungi of some oil seeds. Int. J. Recent Scientific Res.,
6(2): 2813-2816.

Nagamani, A., Kunwar, I.K., Manoharachary, C. 2006. Handbook of Soil Fungi. I. K. International Pvt. Ltd., New Delhi.

Naik, S.N., Vaibhav, V., Goud Prasant, K.R. and Ajay, K.D. 2010. Production of first and second generation biofuels: A comprehensive review. Renewable and Sustainable Energy Reviews, 14: 578-597.

Nijaguna, B.T. 2012. Biogas Technology. New Age International Publishers (P) Ltd., New Delhi.

Reddy, P.L.N., Suresh Babu, B., Radhaiah, A. and Sreeramulu, A. 2014. Screening, identification and isolation of cellulolytic fungi from soils of Chittoor district, India. Int. J. Curr. Microbiol. Appl. Sci., 3(7): 761-771.

Saleem, A., El-Said, A.H.M., Moharram, A.M. and Abdelnaser, E.G. 2013. Cellulolytic activity of fungi isolated from anise and cumin spices and potential of their oils as antifungal agents. J. Med. Plants Res., 7(17): 1169-1181.

\section{How to cite this article:}

Patil, V.S., and Deshmukh, H.V. 2016. Studies on Molds from Vegetable Waste, Cattle Dung Slurry and Biogas Digester Effluent. Int.J.Curr.Microbiol.App.Sci. 5(9): 182-189. doi: http://dx.doi.org/10.20546/ijcmas.2016.509.020 